\title{
Analisis Penerapan Sistem Pengendalian Intern Pemerintah (SPIP) terhadap Barang Milik Daerah Pemerintah Kota Bitung
}

\author{
PITER MANGNGA’ MADESEN ${ }^{1}$, HERMAN KARAMOY ${ }^{2}$, LINDA LAMBEY ${ }^{3}$
}

\author{
${ }^{123}$ Program Magister Akuntansi, Fakultas Ekonomi dan Bisnis Universitas Sam Ratulangi \\ email: pitermangnga@yahoomail.co.id ${ }^{1}$,hermankaramoy@yahoo.com ${ }^{2}$, lindalambey@yahoo.com ${ }^{3}$
}

\begin{abstract}
The objective of this research is to analyze the implementation of Government Internal Control System (SPIP) to Bitung City Government Property, analyze the constraints faced and the efforts made for better implementation. This research uses qualitative method with case study approach. Data obtained through in-depth interview technique, observation and documentation study. Key informants are determined by purposive sampling with the requirement to meet the criteria set to obtain accurate and accurate information. Triangulation techniques are used to te st the validity of data and data sources. The transcripts described in the interviews were analyzed using analytical methods consisting of theme / coding, conceptualizing scientific statements and interpreting them in narrative form. The results showed that the implementation of Government Internal Control System (SPIP) has not been implemented in accordance with the regulations set by the Government. The obstacles faced by SPIP are not understood, the legal basis / rule is not implemented, the lack of competence of human resources, communication and information are not going well, the lack of commitment of each person in charge and the lack of facilities, infrastructure and technical guidance. Efforts made by reconciliation of goods management with Asset Sector, optimization of SIMDA BMD utilization, asset clinic and budget addition.
\end{abstract}

Keywords: Application of SPIP, Regional Property, Human Resources.

\begin{abstract}
Abstrak. Penelitian ini bertujuan untuk menganalisis penerapan Sistem Pengendalian Intern Pemerintah (SPIP) terhadapa Barang Milik Daerah Pemerintah Kota Bitung, menganalis is kendala yang dihadapi serta upaya-upaya yang dilakukan untuk penerapan yang lebih baik. Penelitian ini menggunakan metode kualitatif dengan pendekatan studi kasus. Data di peroleh melalui teknik wawancara secara mendalam, observasi dan studi dokumentasi. Informan kunci ditetapkan secara purposive sampling dengan syarat memenuhi kriteria yang di tetapkan untuk mendapatkan informasi yang tepat dan akurat. Teknik triangulasi digunakan untuk menguji validitas data dan sumber data. Data transkrip yang di uraikan dari hasil wawancara dianalisis menggunakan metode analisis y ang terdiri dari pemberian tema/coding, konseptualisasi pernyataan ilmiah dan menginterp reta sik an nya dalam bentuk narasi. Hasil penelitian menunjukkan bahwa penerapan Sistem Pengendalian Intern Pemerintah (SPIP) belum dilaksanakan sesuai dengan regulasi yang di tetapkan oleh Pemerintah. Kendala yang dihadapi yakni SPIP belum dipahami, dasar hukum/aturan tidak dilaksanakan, kurangnya kompetensi sumber daya manusia, komunikasi dan informasi yang tidak berjalan dengan baik, kurangnya komitmen setiap penanggung jawab dan masih kurangnya sarana, prasarana dan bimbingan teknis. Upaya yang dilakukan rekonsiliasi pengurus barang dengan Bidang Aset, optimalisasi pemanfaatan SIMDA BMD, klinik aset serta penambahan anggaran.
\end{abstract}

\section{Kata kunci: Penerapan SPIP, Barang Milik Daerah, Sumber Daya Manusia.}

\section{Pendahuluan}

Undang-undang Nomor 1 tahun 2004 tentang Perbendaharaan Negara pada pasal 58 ayat (1) dan (2) menyebutkan bahwa dalam rangka meningkatkan kinerja, transparansi dan akuntabilitas pengelolaan keuangan negara, Presiden selaku Kepala Pemerintah mengatur dan menyelenggarakan Sistem Pengendalian Intern di lingkungan pemerintah secara menyeluruh. Sistem Pengendalian Intern ditetapkan dengan Peraturan Pemerintah. Selanjutnya pada Peraturan Pemerintah nomor 8 tahun 2006 tentang Pelaporan Keuangan dan Kinerja Instansi Pemerintah pada pasal 33 ayat (1) dijelaskan bahwa untuk meningkatkan keandalan laporan 
keuangan dan kinerja sebagaimana diatur dalam Peraturan Pemerintah tersebut, setiap entitas pelapor dan entitas akuntansi wajib menyelenggarakan Sistem Pengendalian Intern sesuai ketentuan peraturan dan perundang-undangan yang terkait. Oleh karena itu dalam pemeriksaan Laporan Keuangan Pemerintah Daerah (LKPD), Badan Pemeriksa Keuangan (BPK) wajib menguji dan menilai Sistem Pengendalian Intern (SPI) Pemerintah Daerah yang bersangkutan. Salah satu kriteria pemberian opini adalah evaluasi atas efektivitas Sistem Pengendalian Intern (SPI). Dengan kondisi seperti itu tampak bahwa Sistem Pengendalian Intern (SPI) memiliki peran yang penting untuk mewujudkan tata kelola yang baik (Good Governance) atas Sistem Pengelolaan Keuangan Negara/Daerah. Namun dalam perjalanannya pelaksanaan Sistem Pengendalian Intern (SPI) mendapatkan kendala antara lain: pengabaian manajemen, perspektif yang tidak mendukung, dan kompetensi Sumber Daya Manusia (SDM) yang kurang memadai serta ad anya praktik KKN.

Oleh karena itu pada tahun 2008 Pemerintah mengeluarkan Peraturan Pemerintah Nomor 60 tahun 2008 tentang Sistem Pengend alian Intern Pemerintah (SPIP). Penerapan SPIP di lingkungan instansi pemerintah diharapkan dapat mendorong terciptanya reformasi birokrasi dan tata kelola pemerintahan yang lebih baik. Hal ini dikarenakan Sistem Pengendalian Intern Pemerintah (SPIP) mempunyai 4 tujuan yang ingin dicapai yaitu;

(1) Kegiatan yang efektif dan efisien

(2) Laporan keuangan yang dapat diandalkan,

(3) Pengamanan Aset negara, dan

(4) Ketaatan terhadap peraturan perundang-undangan.

Kualitas Sistem Pengendalian Intern Pemerintah (SPIP) pada Satuan Kerja Perangkat Daerah (SKPD) merupakan salah satu instrumen dalam pencapaian tujuan bersama (goal congruence) Pemerintah Daerah. Keberhasilan Sistem Pengendalian Intern Pemerintah (SPIP) pada pengelolaan keuangan SKPD dapat tercermin dalam opini yang diberikan Badan Pemeriksa Keuangan pada Hasil Pemeriksaan Laporan Keuangan Pemerintah Daerah (LKPD).

Syamsuddin (2016) menyatakan bahwa banyak Instansi Pemerintah masih menganggap bahwa pengelolaan aset secara fisik hanyalah sekedar instrumen pengelolaan daftar aset. Realita di lapangan menunjukkan banyak kasus yang sebenarnya dimulai dari salah kelola dan salah urus masalah aset, sehingga berdampak kerugian yang tidak sedikit dan di pemerintahan sendiri sangat berpengaruh terhadap opini laporan keuangan yang menjadi salah satu bentuk penilaian atas akuntabilitas pengelolaan keuangan daerah. Pengelolaan aset daerah sebenarnya merupakan bagian yang tidak terpisahkan dari pengelolaan keuangan daerah dan secara umum terkait dengan adiministrasi pembangunan daerah khususnya yang berkaitan dengan nilai aset, pemanfaatan aset, pencatatan nilai aset dalam neraca, maupun dalam penyusunan prioritas dalam pembangunan.

Ketidakakuratan sistem pencatatan aset disebabkan oleh berbagai faktor, antara lain tidak didukung dengan bukti kepemilikan bahkan aset tanah yang belum memiliki sertifikat. Permasalahan dalam pengelolaan aset daerah membutuhkan keseriusan Pemerintah Daerah untuk menata pengelolaannya, mulai dari perencanaan hingga pemanfaatan dan pengawasannya. Setidaknya tata kelola tersebut dapat meminimalkan berbagai penyimpangan yang ada, termasuk temuan BPK dalam pemeriksaan laporan keuangan setiap tahun anggaran. Sutaryo (2010) menyatakan bahwa pengelolaan aset daerah bukanlah pekerjaan yang mudah. Hal ini terbukti dari masih banyaknya pengecualian kewajaran atas nilai aset pemerintah daerah dalam opini BPK atas laporan keuangan pemerintah daerah.

Dari hasil temuan Badan Pemeriksa Keuangan Republik Indonesia Perwakilan Sulaw esi Utara terkait Sistem Pengendalian Intern tahun 2016 khususnya yang berkaitan dengan Aset/Barang Milik Daerah, pada Pemerintah Daerah Kota Bitung, memuat:

1. Pengelolaan dan Penatausahaan Aset Tetap pada Pemerintah Kota Bitung Belum Memadai:

a. Data Aset Tetap Dalam Buku Inventaris dan KIB (Kartu Inventaris Barang) belum dicatat secara Informatif, tidak didukung dengan bukti kepemilikan dengan Nilai sebesar 
Rp. 4.845.501.000,- (empat milyar delapan ratus empat puluh lima juta lima ratus satu ribu rupiah).

b. Aset Tanah Belum Memiliki Sertifikat sebanyak 607 (enam ratus tujuh) persil

c. Proses Tuntutan Ganti Rugi Atas Aset Tetap yang hilang belum dilakukan sebesar Rp. 1.417.924.181,- (satu milyar empat ratus tujuh belas juta sembilan ratus dua puluh empat ribu seratus delapan puluh satu rupiah).

d. Aset yang dalam kondisi rusak berat masih tercatat sebagai aset tetap sebesar Rp. 16.320.390.771,- (enam belas milyar tiga ratus dua puluh juta tiga ratus sembilan puluh ribu tujuh ratus tujuh puluh satu rupiah).

e. Aset tetap dari bantuan danhibah pemerintah pusat belum tercatat sebesar Rp. 6.284.165.000,- (enam milyar dua ratus delapan puluh empat juta seratus enam puluh lima ribu rupiah).

f. Terdapat Ruas jalan baru yang belum di tetapkan dengan SK ruas jalan sebesar Rp 36.067.597.000,- (tiga puluh enam milyar enam puluh tujuh juta lima ratus sembilan puluh tujuh ribu rupiah).

2. Pengelolaan Aset lainnya tidak tertib sebesar Rp. 65.942.354.673,-- (enam puluh lima milyar sembilan ratus empat puluh dua juta tiga ratus lima puluh empat ribu enam ratus tujuh puluh tiga rupiah).

Peraturan Pemerintah No 60 Tahun 2008 tentang Sistem Pengendalian Intern Pemerintah pada unsur ketiga Kegiatan Pengendalian poin tiga bagian (d) Pengendalian fisik atas aset ; Pimpinan Instansi Pemerintah wajib melaksanakan pengendalian fisik atas aset. Dalam rangka pengendalian fisik atas aset sebagaimana dimaksud, pimpinan Instansi Pemerintah wajib menetapkan, mengimplementasikan dan mengkomunikasikan kepada seluruh pegawai: rencana identifikasi, kebijakan, dan prosedur pengaman fisik; rencana pemulihan setelah bencana. Serta bagian (h) Pencatatan yang akurat dan tepat waktu atas transaksi dan kejadian; Dalam melakukan pencatatan yang akurat dan tepat waktu pimpinan Instansi Pemerintah perlu mempertimbangkan: transaksi dan kejadian diklasifikasikan dengan tepat dan dicatat dengan segera dan dalam seluruh siklus transaksi atau kejadian.

Penelitian ini bertujuan untuk: 1). Mengalisa penerapan Sistem Pengendalian Intern Pemerintah (SPIP) terhadap Barang Milik Daerah di Pemerintah Kota Bitung; 2). Untuk mengetahui upaya-upaya yang dilakukan oleh Pemerintah Kota Bitung dalam penerapan Sistem Pengendalian Intern Pemerintah (SPIP) terhadap Barang Milik Daerah

\section{Model Analisis}

Model analisis dalam penelitian ini diawali dengan melihat penerapan Sistem Pengendalian Intern Pemerintah terhadap Barang Milik Daerah kemudian menentukan topik penelitian. Selanjutnya melakukan pengumpulan data dengan wawancara serta studi dokumentasi dan observasi. Data yang dikumpulkan diolah, serta diuji kebsahannya lalu menarik kesimpulan.

\section{Metode Penelitian}

Penelitian ini menggunakan strategi pendekatan metode studi kasus karena peneliti akan menyelidiki secara cermat suatu program, peristiwa, aktivitas, proses atau sekelompok individu. Kasus-kasus dibatasi oleh waktu dan aktivitas, dan peneliti mengumpulkan informasi secara lengkap dengan menggunakan berbagai prosedur pengumpulan data berdasarkan waktu yang ditentukan (Creswell, 2010).

Teknik pengumpulan data yang digunakan dalam penelitian ini adalah melalui wawancara mendalam (in-depth interview), observasi / pengamatan dan studi dokumentasi atau gabungan ketiganya. Informan kunci ditetapkan secara purposive sampling dengan syarat memenuhi kriteria yang ditetapkan untuk mendapatkan informasi yang tepat dan akurat. 
Wawancara dilakukan kepada pengurus barang Dinas Pekerjaan Umum, Dinas Pendidikan, Dinas Kesehatan, kepala seksi di bidang aset BPKAD, kepala bidang akuntansi, dan Inspektorat Kota Bitung. Teknik pengujian keabsahan data hasil penelitian, mengunakan triangulasi. Untuk teknik analisis data, mengunakan metode analisis isi (content analysis) yang menurut Miles and Huberman dalam Satori (2013) terdiri atas data reduction, data display dan conclusion drawing/verification yang dilakukan secara interaktif dan berlangsung secara terus menerus sampai tuntas, sehingga datanya mencapai jenuh. uji keabsahan data dalam penelitian kualitatif meliputi uji credibility (validitas internal), transferability (validitas eksternal), dependability (reliabilitas) dan confirmability (objektivitas) Sugiyono (2014).

\section{Analisis dan Pembahasan}

Penelitian dilaksanakan di kantor Inspektorat, Dinas Pekerjaan Umum, Dinas Pendidikan, Dinas Kesehatan serta di Badan Pengelola Keuangan dan Aset Daerah Kota Bitung selama 3 (tiga) bulan yakni bulan November 2017 sampai dengan bulan Januari 2018. Instrumen pendukung yang digunakan adalah: buku catatan (notebook), pedoman wawancara, alat perekam berupa audio (voice recorder) / video recorder (handycam) untuk merekam pelaksanaan wawancara dengan informan yang hasilnya di transcribe menjadi transkrip data, kamera untuk mendokumentasikan kegiatan penelitian di lapangan, dan laptop untuk menunjang penulisan hasil penelitian. Adapun hasil penelitian dan pembahasan ditemukan 7 (tujuh) tema yakni 1) SPIP belum dimengerti; 2) dasar hukum; 3) sumber daya manusia; 4) informasi dan komunikasi; 5) disposisi atau sikap: 6) anggaran serta 7) upayaupaya yangdilakukan untuk mengatasi masalah yang diuraikan sebagai berikut:

\section{Sistem Pengendalian Intern Pemerintah (SPIP) yang belum dipahami}

Peraturan Pemerintah No. 60 Tahun 2008 mendefenisikan sistem pengendalian intern adalah proses yang integral pada tindakan dan kegiatan yang dilakukan secara terus menerus oleh pimpinan dan seluruh pegawai untuk memberikan keyakinan memadai atas tercapainya tujuan organisasi melalui kegiatan yang efektif dan efisien, keandalan pelaporan keuangan, pengamanan aset negara, dan ketaatan terhadap peraturan perundang-undangan. Ketidak pahaman SPIP diungkapkan seperti berikut:

"Dia pe sistem itu pengaturan lewat komputer, dilakukan rekon, dilakukan rekonsiliasi dengan pengurus barang. Menurut saya begitu. Jadi ada panggilan untuk di lakukan sistem pengendalian informasi dengan bagian aset" (Informan 6, Commented A103)

Nana Sudjana(1992) bahwa pemahaman dapat dibedakan kedalam 3 kategori yaitu : (1) tingkat terendah adalah pemahaman terjemahan, mulai dari menerjemahkan dalam arti yang sebenarnya, mengartikan dan menerapkan prinsip-prinsip, (2) tingkat kedua adalah pemahaman penafsiran yaitu menghubungkan bagian-bagian terendah dengan yang diketahui berikutnya atau menghubungkan beberapa bagian grafik dengan kejadian, membedakan yang pokok dengan yang tidak pokok dan (3) tingkat ketiga merupakan tingkat pemaknaan ekstrapolasi.

Memiliki pemahaman tingkat ekstrapolasi berarti seseorang mampu melihat dibalik yang tertulis, dapat membuat estimasi, prediksi berdasarkan pada pengertian dan kond isi yang diterangkan dalam ide-ide atau simbol, serta kemampuan membuat kesimpulan yang dihubungkan dengan implikasi dan konsekuensinya.

\section{Dasar Hukum}

Dalam pelaksanaan SPIP di Pemerintah Kota Bitung tetap diatur dengan Peraturan Walikota nomor 29 tahun 2010 dengan merujuk ke Peraturan yang lebih tinggi namun dalam pelaksanaannya belum sepenuhnya diterapkan: 
"Pemerintah Kota Bitung pada prinsipnya sudah melaksanakan SPIP sesuai Perwako yang dimaksud tadi, namun belum sepenuhnya. "(Informan 1, Commented A3)

Standar operasional prosedur merupakan kumpulan peraturan yang dibuat untuk memudahkan setiap tugas pekerjaan, dan untuk instansi pemerintahan, SOP berfungsi untuk mempermudah para pegawai pemerintah dalam melaksankan tugas pokok dan fungsinya masing-masing. Dari hasil wawancara tersebut diatas dapat ditarik kesimpulan bahwa SOP telah ada di masing-masing instansi, demikian pula dalam proses yang berkaitan dengan barang milik daerah ada standar operasional prosedurnya yang ditetapkan secara tertulis, dan harus dilaksanakan sesuai yang di tetapkan secara tertulis. Dalam setiap proses yang berkaitan dengan barang milik daerah mulai dari pengadaan sampai dengan pemusnahan telah dibuatkan Standar Operasional Prosedur (SOP) namun dalam pelaksanaanya belum dilakukan dengan baik. Menurut Tjipto Atmoko (2011), Standar Operasional Prosedur (SOP) merupakan suatu pedoman atau acuan untuk melaksanakan tugas pekerjaan sesuai dengan fungsi dan alat penilaian kinerja instansi pemerintah berdasarkan indikator-indikator teknis, adminstratif dan prosedural sesuai tata kerja, prosedur kerja dan sistem kerja pada unit kerja yang bersangkutan. Dengan demikian fungsi SOP untuk memperlancar tugas petugas/pegawai, sebagai dasar hukum bila terjadi penyimpangan, mengetahui denga jelas hambatan-hambatannya dan mudah dilacak, mengarahkan petugas/pegawai untuk sama-sama disiplin dalam bekerja dan sebagai pedoman dalam melaksanakan pekerjaan rutin (Hartatik, 2014).

\section{Sumber Daya Manausia}

Sumber daya manusia adalah tenaga kerja atau pegawai di dalam suatu organisasi yang mempunyai peran penting dalam mencapai keberhasilan hal ini dikatakan oleh Sedarmayanti (2001) dalam buku "Sumber Daya Manusia dan Produktivitas Kerja". Dari hasil wawancara yang terkait dengan tema Sumber Daya Manusia maka di temukan 5 (lima) sub tema yaitu: kurangnya kompetensi, kurangnya pelaksanaan bimbingan teknis yang menambah pemahaman dan wawasan serta lebih spesifik, beban pekerjaan yang terlalu banyak / work overload, kurangnya tanggung jawab dan komitmen, kurangnya reward dari pimpinan.

\section{Komunikasi yang tidak berjalan dengan baik}

Salah satu unsur Sistem Pengendalian Intern Pemerintah adalah Informasi dan komunikasi bahwa informasi yang berhubungan perlu diidentifikasi, dicatat dan dikomunikasikan dalam bentuk dan waktu yang tepat yang memungkinkan para pihak memahami tanggung jawab. Sistem informasi menghasilkan laporan, kegiatan usaha, keuangan dan informasi yang cukup untuk memungkinkan pelaksanaan dan pengawasan kegiatan instansi pemerintah, berbeda dengan hasil wawancara yang di sampaikan oleh para informan sebagai berikut:

“...barang-barang yang pengadaannya sebelum kita menjabat, dokumen-dokumen pendukungnya sangat kurang, jadi itu yang membuat kami sangat terkendala ketika kami membuat laporan misalnya, penatausahaan barang, mencatat nomor dan nomor kontraknya, itu yang membuat sangat sulit, jadi dokumen-dokumen pendukungnya kurang."

Goldhaber (1990) memberi definisi komunikasi organisasi adalah proses menciptakan dan saling menukar pesan dalam satu jaringan hubungan yang saling tergantung satu sama lain untuk mengatasi lingkungan yang tidak pasti atau selalu berubah-ubah. Definisi ini mengandung tujuh konsep kunci yaitu proses, pesan, jaringan, saling tergantung, hubungan, 
lingkungan dan ketidakpastian.

\section{Employees Work behavior}

Kendala lain yang dihadapi dalam penerapan Sistem Pengendalian Intern Pemerintah terhadap Barang Milik Daerah adalah disposisi atau sikap dari pelaksana kebijakan tersebut. Disposisi adalah watak atau karakteristik yang dimiliki oleh implementor, seperti komitmen, kejujuran dan sifat demokrasi. Dalam penerapan sistem pengendalian intern pemerintah terhadap barang milik daerah adalah sikap dari pelaksana menjadi salah satu kendala seperti pernyataan beberapa informan sebagai berikut:

“...nah cuma sama deng tadi kita bilang tergantung juga masalah orangnya mengerti ndak." (Informan 1, Commented A27)

“...kendala ya itu, salah satunya SDM yang kurang tahu, ada yang sudah tahu tapi tidak mau melakukan, ada yang memang tidak mau tahu." (Informan 5, Commented A94)

Sikap kerja dapat di jadikan ukuran apakah suatu pekerjaan berjalan lancar atau tidak. Jika sikap kerja dilaksanakan dengan baik, pekerjaan akan berjalan lancar. Jika tidak berarti akan mengalami kesulitan. Menurut Blum and Naylor dalam Aniek (2005) ada beberapa faktor yang berpengaruh terhadap sikap kerja yakni; kondisi kerja, pengawasan atasan, kerjasama dari teman sekerja, keamanan, kesempatan untuk maju, fasilitas kerja, upah atau gaji. Sedang menurut Van Meter dan Van Horn (1975), ada enam variabel yang mempengaruhi kinerja implementasi, yakni: (1) standar dan sasaran kebijakan; (2) sumber daya; (3) komunikasi antar organisasi dan penguatan aktivitas; (4) karakteristik agen pelaksana; (5) disposisi implementor; (6) kondisi sosial, ekonomi dan politik.

\section{Kurang memadainya sarana, prasarana serta bimbingan teknis}

Kendala yang terakhir adalah kurang memadainya sarana, prasarana serta bimbingan teknis seperti yang disampai oleh para informan sebagai berikut:

"Memang yang kendala ke kita selama ini kan khusus untuk untuk pengelolaan barang memang belum ada gudang salah satu, cuma kami siasati tentang pengelolaan barang, misalnya kami distribusikan barang itu ke semua sekokah pak, jadi di bentuk pengurus-pengurus barang di setiap kecamatan untuk mengontrol barang yang diserahkan ke sekolah-sekolah negeri." (Informan 3, Commented A39)

- Ketersediaan sarana dan prasarana salah satu yang dapat menentukan keberhasilan suatu pekerjaan seperti yang dikatakan oleh J. Coyle-Shapiro, K. Hoque, I. Kessler, A. Pepper, R. Richardson dan L. Walker (2013) salah satu strategi peningkatan kinerja seorang pekerja adalah, perusahaan harus menyediakan fasilitas penunjang yang dapat membantu dan mempermudah dia dalam melaksanakan tugas-tugasnya.

\section{Upaya-upaya yang dilakukan untuk mengatasi permasalahan}

Untuk mengatasi permasalahan tersebut diatas upaya-upaya yang dilakukan adalah: rekosiliasi yang dilakukan antara pemegang/pengurus barang dengan bidang aset, optimalisasi pemanfaatan SIMDA BMD, klinik aset serta pendampingan yang dilakukan oleh BPKAD bidang aset yang dapat di jelaskan seperti berikut:

Pengelolaan barang milik daerah atau aset perlu ketelitian dan ketekunan karena terkait dengan angka-angka dalam belanja Modal Pemerintah, sering kali terjadi perbedaan antara 
yang ada di SKPD dengan yang ada di Bidang Aset (SIMDA BMD) BPKAD, upaya yang dilakukan dalam mengatasi permasalahan yang telah dikemukakan sebelumnya yakni diadakannya rekonsiliasi antara pengurus barang di SKPD dengan Bidang Aset BPKAD. Peraturan Pemerintah Nomor 8 Tahun 2006 tentang Pelaporan Keuangan dan Kinerja Instansi Pemerintah Pasal 33 menyatakan bahwa sistem pengendalian intern yang andal harus diciptakan prosedur rekonsiliasi antara transaksi keuangan yang diakuntansikan oleh pengguna Anggaran / Kuasa Pengguna Anggaran dengan data transaksi keuangan yang diakuntansikan oleh Bendahara Umum Negara / Daerah. Usaha kedua yang dilakukan pemerintah kota lewat pemanfaatan Aplikasi SIMDA (Sistem Informasi Manajemen Daerah) yang dikembangkan oleh Badan Pengawas Keuangan dan Pembangunan (BPKP) dan dikenal dengan Aplikasi SIMDA merupakan salah satu produk dari teknologi sistem informasi yang digunakan oleh banyak pemerintah daerah di Indonesia dalam menyelenggaraan pengelolaan keuangan dan barang daerahnya. Dengan adanya Aplikasi SIMDA BMD memberikan manfaat yang sangat baik. Aplikasi SIMDA merupakan aplikasi database yang bertujuan mempermudah pengelolaan keungan dan aset di lingkungan Satuan Kerja Perangkat Daerah (SKPD). Aplikasi SIMDA dikembangkan dengan memperhatikan dan mengimplementasikan Sistem Pengendalian Intern Pemerintah (SPIP). Oleh sebab itu pengendalian dan pemanfaatan terhadap aplikasi menjadi suatu keharusan bagi pemerintah daerah. Menurut BPKP (2008) tujuan diterapkannya aplikasi SIMDA:

- Sebagai tempat tukar menukar informasi bagi setipa unit kerja sama penerima koneksitas jaringan SIMDA

- Sebagai alat komunikasi langsung dengan menggunakn webcam bagi unit kerja penerima koneksitas jaringan SIMDA

- Sebagai salah satu media kontrol bagi realisasi kegiatan baik capaian fisik maupun penyerapan dananya

- Sebagai media awal bagi pelaksanaan e-government dan

- Sebagai sarana untuk pelaksanaan good government

Dan manfaat yang diperoleh pemerintah daerah dengan menggunakan SIMDA sebagai berikut:

- Database terpadu, tidak perlu input berulang-ulang untuk data yang sama

- Data yang sama akan tercek dan recek secara otomatis (validasi data terjamin)

- Fleksibel, dapat menghasilkan informasi sesuai dengan kebutuhan dimana;

- Output dapat disesuaikan menurut perundang-undangan yang berlaku, dan

Output dapat disajikan berdasarkan kebutuhan manajemen pemerintah daerah untuk pengambilan keputusan/kebijakan. Dan usha yang ketiga adalah Pemerintah Kota Bitung melakukan klinik aset dan pendampingan untuk setiap permasalahan aset yang dihadapi oleh setiap SKPD, sesuai dengan Keputusan Kepala BPKAD kota Bitung No. 900/BPKBMD/166. Dimulai dengan membangun mindset untuk menyatukan pemahaman tentang pengelolaan aset yang baik melalui Klinik Aset, dan di lakukan pertama-tama Untuk Pimpinan dan Staf Badan Pengelola Keuangan dan Barang Milik Daerah, kemudian menyatukan persepsi tentang pengelolaan aset yang baik kepada pengurus barang SKPD, membekali Tim klinik Aset serta menyiapkan sarana dan prasarana yang diperlukan. Melalui klinik aset ini maka laporan aset disajikan sesuai dengan peraturan perundang undangan yang berlaku dan dilakukan secara tepat waktu.

\section{Penutup}

Kesimpulan Penelitian tentang Penerapan Sistem Pengendalian Intern Pemerintah (SPIP) terhadap Barang Milik Daerah berikut:

1. Adanya perbedaan pemahaman bahkan tidak memahami konsep dasar dari Sitem Pengendalian Intern Pemerintah. SPIP hanya dipahami sebagai pengawasan semua kegiatan-kegiatan yang ada di pemerintah daerah dan yang lain menyatakan bahwa SPIP itu hanya pengaturan lewat komputer, dilakukan rekonsiliasi dengan pengurus barang. 
2. Dasar hukum sudah ada seperti Standar Operasional Prosedur (SOP), namun tidak dilaksanakan

3. Sumber daya manusia merupakan salah satu kendala baik ari segi kualifikasi dan kompetensi, kurangnya bimbingan teknis, beban kerja yang overload, kurangnya tanggung jawab dan komitmen serta kurangnya reward dari pimpinan.

4. Komunikasi yang kurang baik, sikap atau disposisi serta tanggung jawab menjadi faktorfaktor penyebab belum tercapainya penerapan SPIP pada BMD kota Bitung

5. Upaya yang telah dilakukan pemerintah kota Bitung melalui rekonsiliasi aset, klinik aset serta pendampingan bagi pengurus barang.

Saran yang dapat diberikan dari penelitian ini untuk Penerapan Sistem Pengendalian Intern Pemerintah (SPIP) terhad ap Barang Milik Daerah berikut:

1. Perlu memahami Sistem Pengendalian Intern Pemerintah lebih dalam dari teori serta dasar hukum hingga penerapannya dalam barang milik daerah di Pemerintah Kota Bitung

2. Standar Operasional Prosedur yang ada hendaknya di jalankan dan yang belum ada segera di buatkan

3. Perlu peningkatan sumber daya manusia baik dari segi kualitas, kompetensi, tanggung jawab lewat bimbingan teknis, dan pemeberian reward yang cukup bagi pengurus barang

4. Perlunya komunikasi yang baik antar setiap pelaksana pengurus barang

5. Perlunya perencanaan yang matang untuk bimbingan teknis baik dari segi materi yang akan di sampaikan maupun frekwensi pengadaannya.

6. Perlunya penambahan personal atau rekrutmen pegawai yang mempunyai kompetensi sesuai dengan kebutuhan

7. Perlunya ditata dalam Anggran Belanja dan Pendapatan Daerah untuk anggaran Pelatihan serta anggaran kesejahteraan pengurus barang.

\section{Daftar Pustaka}

Aniek. 2005. Sikap manusia, teori dan pengukurannya, Yogyakarta: Pustaka Pelajar.

Atmoko, Tjipto. 2011. Standar Operasional Prosedur (SOP) dan Akuntabilitas Kinerja Instansi Pemerintah. Bandung: Unpad.

Coyle-Shapiro J., K. Hoque, I. Kessler, A. Pepper, R. Richard son dan L. Walker. 2013. Human Resource Management: Undergraduate Study in Economics, Finance and Social Science. University of London.

Creswell, J. W. 2010. Terjemahan; Research Design: Pendekatan kualitatif, kuantitatif, dan mixed. Yogjakarta: PT. Pustaka Belajar.

Goldhaber, M, Gerald. 1990. Organizational Communication. Wm C Brown Publisher.

Hartatik, Indah Puji. 2014. Buku Pintar Membuat S.O.P (Standard Operating Procedure), Jogjakarta: Flashbooks

Meter, Donald S. Van dan Carl E. Vanhorn. 1975.The Policy Implementation Process: A Conceptual Framework. Ohio State University

Nana Sudjana, 1992. Penilaian Hasil Proses Belajar Mengajar. Bandung: PT. Remaja Rosdakarya.

Satgas Pengembangan SIMDA 2008. SIMDA dan Penerapannya. Jakarta: Badan Pemeriksa Keuangan dan Pembangunan.

Satori, Djam'an dan Aan Komariah. 2013. Metodologi Penelitian Kualitatif. Bandung: Alfabeta.

Sedarmayanti. 2001. Sumber Daya Manusia dan Produktivitas Kerja. Bandung: Mandar Maju.

Sugiyono. 2014. Metode Penelitian Bisnis Pendekatan Kualitatif Kuantitatif Kombinasi dan R\&D. Bandung: Alfabeta

Sutaryo. 2010. Manajamen Aset Daerah. Jurnal Akuntansi FE UNS. Halaman1-9. Universitas Negeri Semarang. 
Syamsuddin. 2016. Pentingnya Manajemen Aset. Universitas Islam Negeri Alauddin. Makassar.

\section{Peraturan-peraturan:}

Pemerintah Kota Bitung. 2015. Keputusan Kepala Badan Pengelola Keuangan dan Barang Milik Daerah.

Republik Indonesia. 2004. Undang-Undang No. 1 Tentang Perbendaharaan Negara. Jakarta -. 2006. Peraturan Pemerintah N0. 8 Tentang Pelaporan Keuangan dan Kinerja Instansi Pemerintah. Jakarta 2008. Peraturan Pemerintah NO. 60 Tentang Sistem Pengendalian Intern Pemerintah. Jakarta 